\title{
List of Authors - The Forestry Chronicle, Volume 62, 1986
}

Anderson, M.L. See: Schooley, H.O., D.A. Winston, R.L. Macnaughton and M.L. Anderson.

Armson, K.A. Chemicals and our forests. 62(4): 379-382.

Ascher, A. See: Newstead, R.G. and A. Ascher.

Baskerville, G.L. Understanding forest management. 62(4): 339-347.

Beck, James A. See: Phillips, William E. and G.W. Lamble.

Bella, I.E. Logging practices and subsequent development of aspen stands in east-central Saskatchewan. 62(2): 81-83.

Bella, I.E. Tree growth response along seismic lines in Alberta. 62(1): 29-34

Berry, A.B. See: Stiell, W.M. and A.B. Berry.

Borden, J.H., L.J. Chong aand T.E. Lacey. Pre-logging baiting with semiochemicals for the mountain pine beetle, Dendroctonus ponderosae, in high hazard stands of lodgepole pine. 62(1): 2023

Boulter, D.W.K. Global supply-demand outlook for industrial roundwood. 62(4): 306-313.

Bowersock, J.N. Forest management - the need for trust. 62(4): 356-358

Brand, D.G. and G.F. Weetman. Standards for regeneration establishment in Canada: A case study for Douglas-fir. 62(2): 8490

Bruce, G.P. Strategy for survival - "A forest investment proposal." 62:(4): $369-372$

Burdett, A.N., H. Coates, R. Eremko and P.A.F. Martin. Toppling in British Columbia's lodgepole pine plantations. 62(5): 433-439

Calp, S.C. See: Johnston, M.H. and S.C. Calp.

Camiré, C. See Thérien and C. Camiré.

Carroll, M. See: MacDonald, A.P. and M. Carroll.

Carter, R.E., I.M. Miller and K. Klinka. Relationship between growth form and stand density in immature Douglas-fir. 62(5): 440-445.

Cayford, J.H. Historical highlights 1958-1983 CIF/IFC. 63(4): 255261.

Cheliak, W. See: Hasnain, S. and W. Cheliak.

Chong, L.J. See: Borden, J.H., L.J. Chong and T.E. Lacey

Coates, H. See: Burdett, A.N., H. Coates, R. Eremko and P.A.F. Martin

Cuthbert, J.R. Not seeing the forest for the timber. 62(4): 376-378.

Demaerschalk, J.P. See: Marshall, P.L. and J.P. Demaerschalk.

Dominy, S.W.T. and J.E. Wood. Shelter spot seeding trials with jack pine, black spruce and white spruce in northern Ontario. 62(5): 446-450

Edwards, D.G.W. and F.T. Portlock. Expansion of Canadian tree seed certification. 62(5): 461-466.

Eidt, D.C. and P.A. Pearce. The biological consequences of lingering fenitrothion residues in conifer foliage. 62(4): 246-249.

Eremko, R. See: Burdett, A.N., H. Coates, R. Eremko and P.A.F. Martin.

Fellows, E.S. Forestry's future frustrated or A condensed history of Canadian foresters' concern for forest renewal. 62(1): 35-50

Fullerton, W.K. National forest conferences in historical perspective. 62(5): 467-469.

Hacker, J.J. See: Webster, H.H. and J.J. Hacker.

Hagner, S.O.A. From mining to industrial forestry: Some Canadian forest problems in an international perspective. 62(2): 101-103.

Hansen, E.A. Planting date affects survival and height growth of hybrid poplar. 62(3): 164-169

Harestad, A.S. See: Harper, P.A. and A.S. Harestad.

Harper, P.A. and A.S. Harestad. Vole damage to coniferous trees on Texada Island $62(5):$ 429-432

Harper, L.M. See: Tanaka, Y., N.J. Kleyn and L.M. Harper.

Harvey, D.A., M.E. Alexander and B. Janz. A comparison of fireweather severity in northern Alberta during the 1980 and 1981 fire seasons, 62(6): 507-513.

Hasnain, S. and $\mathbf{W}$. Cheliak. Tissue culture in forestry: Economic and genetic potential. 62(4): 219-225

Hasnain, S., R. Pigeon and R.P. Overend. Economic analysis of the use of tissue culture for rapid forest improvement 62(4): 240-245.
Holdaway, M.R. Modeling tree crown ratio. 62(5): 451-455

Honer, T.G. Assessing change in Canada's forest resource 1977-81. 62(5): 423-428.

Hopkins, J.C. and C.S. Simmons. Effect of spacing in lodgepole pine stands on incidence of Atropellis canker. 62(2): 91-95.

Johnson, S. Forest regional and sector planning models in New Zealand 62 6$\})$ : 537-541

Johnston, M.H. and S.C. Calp. Forest land use planning in Alberta. 62(5): 470-473.

Kelleher, Hon. J. Canadian interests in forest production trade. 62(4) 314-316.

Klein, J.I. Development of jack pine seed orchard by mass selection 62(3): 143-146.

Kleyn, N.J. See: Tanaka, Y., N.J. Kleyn and L.M. Harper.

Klinka, K. See: Carter, R.E., I.M. Miller and K. Klinka.

Koken, B.K. The future for pulp and paper - Canada's competitive ability. $62(4): 319-321$

Lacate, D.S. See: Redpath D.K. D.S. Lacate and K.E. Moore

Lacey, T.E. See: Borden, J.H., L.J. Chong and T.E. Lacey.

Lamble, G.W. See: Phillips, William E. and James A. Beck.

Lang, A.J. See: Pearse, P.H., A.J. Lang and L.K. Todd.

LaPierre, L. Female red squirrel reproductive tracts from fenitrothion treated and untreated forest of southeastern New Brunswick 62(4): 233-235.

Lavallee, A. Zones de vulnérabilité du pin blanc à la rouille vésiculeuse au Québec. 62(1): 24-28.

MacDonald, A.P. and M. Carroll. An economic analysis of chip utilization in Alberta. 62(4): 250-254

Macnaughton, R.L. See: Schooley, H.O., D.A. Winston, R.L. Macnaughton and M.L. Anderson.

Marshall, P.L. A decision context for timber supply modelling. 62(6): 533-536

Marshall, P.L. and J.P. Demaerschalk. A strategy for efficient sample selection in simple linear regression problems with unequal per unit sampling costs. 62(1): 16-23

Martin, P.A.F. See: Burdett, A.N., H. Coates, R. Eremko and P.A.F. Martin.

McRae, D.J. Prescribed burning for stand conversion in budwormkilled balsam fir: An Ontario case history. 62(2): 96-100.

Merkin, W.S. U.S./Canada trade - a time for action. 62(4): 317-318.

Miller, I.M. See: Carter, R.E., I.M. Miller and K. Klinka.

Moore, K.E. See: Redpath, D.K., D.S. Lacate and K.E. Moore.

Morley, P.M. Management and use of aspen poplar in North America. 62(2): 104-107

Munro, J. Forest employment. 62(4): 367-368.

Newstead, R.G. and A. Ascher. Perceptions of the forestry sector in the Prairie Provinces. 62(3): 178-179.

Overend, R.P. See: Hasnain, S., R. Pigeon and R.P. Overend

Paillé, G. The major elements of a forest sector strategy for Canada 62(4): 392-396.

Parker, G.R. Importance of cover in conifer plantations for snowshoe hares 62(3): 159-163

Pearce, P.A. See: Eidt, D.C. and P.A. Pearce

Pearse, P.H. The challenge of change. 62(3): 175-177

Pearse, P.H., A.J. Lang and K.L. Todd. The backlog of unstocked forest land in British Columbia and the impact of reforestation programs. 62(6): 514-521.

Pearse, P.H., A.J. Lang and L.K. Todd. Economic priorities for reforesting unstocked forest land in British Columbia. 62(6): 522528

Phillips, William E., James A. Beck and G. Wayne Lamble. Forest economics research needs in west-central Canada. 63:(3) 152158

Pigeon, R. See: Hasnain, S., R. Pigeon and R.P. Overend

Portlock, F.T. See: Edwards, D.G.W. and F.T. Portlock. 
Redpath, D.K., D.S. Lacate and K.E. Moore. Land-use change on prime forest land in the Prince George, B.C., region 1965-1981. 62(4): 236-239.

Reed, F.L.C. Canada's timber supply. 62(4): 335-338.

Robertson, A. Teleforestry: Utilizing television. 62(6) 542-545.

Roper, J. and J.V. Thirgood. The tropical forest - problems and solutions. 62(3): 194-201.

Schooley, H.O., D.A. Winston, R.L. Macnaughton and M.L. Anderson. Frost killing of red pine female flowers. 62(3): 140142

Setliff, E.C. Wood decay hazard in Canada based on Scheffer's climate index formula. 62(5): 456-460

Simmons, C.S. See: Hopkins, J.C. and C.S. Simmons

Smith, R.V. Trade in solid wood products - A Canadian perspective 62(4): 322-329.

Stiell, W.M. and A.B. Berry. Productivity of short-rotation aspen stands. $62(1): 10-15$.

Sutton, R.F. Hexazinone Gridballs ${ }^{\text {Tw }}$ applied with concurrent underplanting of white spruce in boreal mixedwoods: 7-year results. $62(4): 226-232$
Tanaka, Y., N.J. Kleyn and L.M. Harper. Seed stratification of Engelmann spruce and lodgepole pine. 62(3): 147-151.

Thérien, $\mathbf{G}$. and $\mathbf{C}$. Camiré. Use of taper curve solved by an algebraic method in silvicultural research. 62(6): 529-532.

Thirgood, J.V. See: Roper, J. and J.V. Thirgood.

Thomas, J.W. Wild life in managed forests - A matter of commitment 62(4): 383-386

Todd, K.L. See: Pearse, P.J., A.J. Lang and K.L. Todd.

Webster, H.H. and J.J. Hacker. Multiple use: Improving on a good idea, and avoiding a red herring. 62(4): 262-264.

Weetman, G.F. The state of Canadian forest management. 62(4): 348-355

Weetman, G.F. See: Brand, D.G. and G.F. Weetman.

Winston, D.A. See: Schooley, H.O., D.A. Winston, R.L. Macnaughton and M.L. Anderson.

Wood, J.E. See: Dominy, S.W.J. and J.E. Wood

Zarnovican, R. La loi d'Eichhorn et les tables de production pour l'épinette noire. 62(3): 170-174.

Zimmerman, A. Jobs in the forest industry. 62(4): 364-366

\section{Reviewers - The Forestry Chronicle, Volume 62, 1986}

Editor.

In addition to thanking the Associate Editors, I wish to thank the following reviewers and apologize to those whose names I have missed. The
T. Adams
P. Aird
I.S. Alemdag
J. Armstrong
W.D. Baker
K. Barr
B.A. Barkley
D.G. Brand
G. Brochu
K. Brown
H.E. Burkhort
W. Carman
G. Carpentier
I.K. Edwards
R.E. Farmer
D.C.F. Fayle
D. Flora
W.K. Fullerton
A. Funk

G. Gertner

J.W. Girard

A. Gonzalez

H.L. Gross

D. Hayden

T. Hazenberg

A. Jeffries

B. van der Kamp

P. Kingsbury

P. Kourtz

D. Lavender

D. Lester

H. Lewis

D.A. MacLean

S. Magnussen

J. Marshall

P.L. Marshall

A. Mauch

J.C. Nautiyal
J. Osborn

S. Pala

B. Pendrel

D. Peralta

M. Roberge

M. Roberts

D. Seip

A. Simard

T. Steele

R.M. Strang

J.S. Tanz

V.R. Timmer

S.J. Titus

G. Vallée

J. Vlcek

D. Walker

E.S. Ward

D. Winston
Change of Address

Date Section

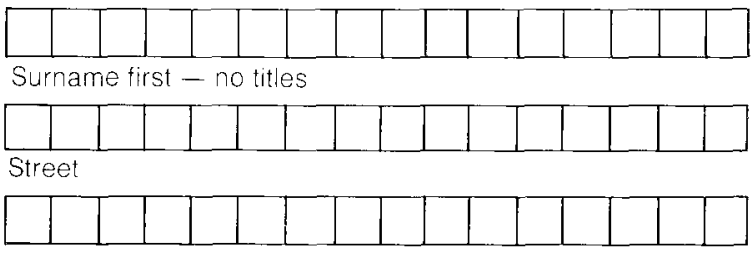

City and Province

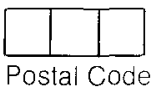

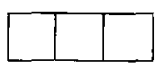

Changement d'adresse

Date Section.

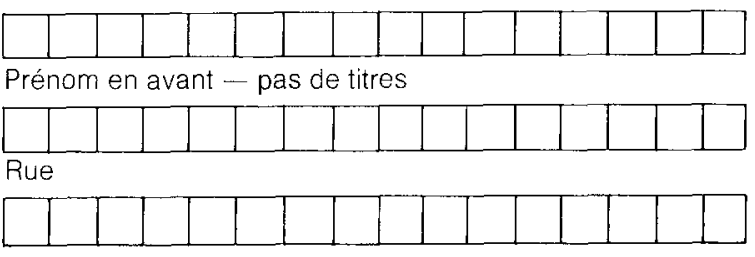

Ville et Province

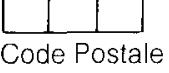

